\title{
ADDITIONAL THREE-POINT DATA FOR LINKAGE GROUP $\vee$ OF THE MOUSE
}

\author{
P. A. PARSONS
}

Department of Genetics, University of Cambridge

Received I I.xi. 57

\section{INTRODUCTION}

THE data reported in this paper are intended to supplement the recent interference data of Owen (I953) and Wallace (I957a) for linkage group $\mathrm{V}$ of the house mouse. Owen's experiment was for the four closely linked markers agouti $(A)$, undulated (un), wellhaarig (we) and pallid $(p a)$, and Wallace's experiment was for agouti, fidget $(f i)$ and Danforth's short-tail $(S d)$. From these studies, and from some affinity data, Wallace ( $1957 b$ ) showed that the centromere is probably between $f i$ and $S d$.

The history of this linkage group is discussed fully in Wallace's (I957a) paper and it will be sufficient merely to give the order of the markers :-

$$
\text { Ra } \quad k r \quad A \quad \text { un we pa fi } \quad \text { Sd }
$$

The experiment to be discussed in this paper is for the three markers ragged $(R a)$-agouti and wellhaarig which are situated some distance from the probable location of the centromere. It is a region of the chromosome not previously studied from the point of view of interference.

\section{DESIGN}

The four possible triple heterozygotes

$$
\frac{R a A+}{+a^{t} w e}, \quad \frac{R a a^{t} w e}{+A+}, \quad \frac{R a A w e}{+a^{t}+}, \frac{R a a^{t}+}{+A w e},
$$

were made up and backcrossed to Awe mice. The symbol $a^{t}$ represents tan belly, an allele of agouti, and the three types $A A, A a^{t}$ and $a^{t} a^{t}$ are readily distinguishable. Data are presented in table I for recombination in both sexes. The data are arranged in a $4 \times_{4}$ Latin square of the form

$\begin{array}{llll}\text { A } & \text { B } & \text { C } & \text { D } \\ \text { B } & \text { A } & \text { D } & \text { C } \\ \text { C } & \text { D } & \text { A } & \text { B } \\ \text { D } & \text { C } & \text { B } & \text { A }\end{array}$

where the columns represent the modes of gamete formation, the rows correspond to the four mating types, and the letters to the four pairs of complementary genotypes. This design has been used by 
Wallace (I947, I957a) and Parsons (1958) in the house mouse, and by other workers in Drosophila and maize. It enables viability differences between different complementary pairs of genotypes to be eliminated, so removing bias from the, recombination fractions.

TABLE I

Observed data

Types of gamete formation

\begin{tabular}{|c|c|c|c|c|c|c|c|c|c|}
\hline $\begin{array}{l}\text { Triply } \\
\text { hetero- } \\
\text { zygous } \\
\text { parent }\end{array}$ & \multicolumn{2}{|c|}{ No change } & $R a \mathrm{c}$ & $\begin{array}{l}\text { hange } \\
\stackrel{+}{\oplus} \quad{ }^{\star}\end{array}$ & \multicolumn{2}{|c|}{ we change } & \multicolumn{2}{|c|}{$A$ change } & ㅇ \\
\hline \multirow[t]{2}{*}{$\frac{R a \cdot A+}{t a^{t} w e}$} & $\begin{array}{l}R a A \\
a^{t} w e\end{array}$ & $\begin{array}{l}57+77 \\
74+63\end{array}$ & $\begin{array}{l}\text { Ra } a^{\prime} \text { we } \\
A\end{array}$ & $\begin{array}{l}19+26 \\
23+20\end{array}$ & $\begin{array}{l}\operatorname{Ra} A \text { we } \\
a^{t}\end{array}$ & $\begin{array}{l}12+7 \\
12+8\end{array}$ & $\begin{array}{l}R a a^{t} \\
A w e\end{array}$ & $\begin{array}{l}I+2 \\
3+0\end{array}$ & \\
\hline & & $131+140$ & & $42+46$ & & $24+$ I 5 & & $4+2$ & $20 \mathrm{I}+2 \mathrm{O} 3$ \\
\hline \multirow[t]{2}{*}{$\frac{\operatorname{Ra} a^{t} w^{\prime} e}{+A+}$} & $\begin{array}{l}\text { Ra } a^{t} \text { we } \\
A\end{array}$ & $\begin{array}{l}75 \div 77 \\
55 \div 57\end{array}$ & $\begin{array}{l}\text { Ra } A \\
a^{t} \text { we }\end{array}$ & $\begin{array}{l}20+19 \\
27+25\end{array}$ & $\begin{array}{l}R a a^{\ell} \\
\text { A we }\end{array}$ & $\begin{array}{l}12+17 \\
16+6\end{array}$ & $\begin{array}{l}\text { Ra A we } \\
a^{t}\end{array}$ & $\begin{array}{l}0+0 \\
0+1\end{array}$ & \\
\hline & & $130+134$ & & $47+44$ & & $28+23$ & & $0+1$ & $205+202$ \\
\hline \multirow[t]{2}{*}{$\frac{\operatorname{RaAwe}}{+a^{t}+}$} & $\begin{array}{l}R a A \text { we } \\
a^{t}\end{array}$ & $\begin{array}{l}66+70 \\
78+72\end{array}$ & $\begin{array}{l}R a a^{t} \\
A \text { we }\end{array}$ & $\begin{array}{l}20+25 \\
16+19\end{array}$ & $\begin{array}{l}\text { RaA } \\
a^{t} \text { we }\end{array}$ & $\begin{array}{l}17+16 \\
10+6\end{array}$ & $\begin{array}{l}\text { Ra } a^{t} w e \\
A\end{array}$ & $\begin{array}{l}2+0 \\
0+I\end{array}$ & \\
\hline & & $144+142$ & & $36 \div 44$ & & $27+22$ & & $2+1$ & $209+209$ \\
\hline \multirow[t]{3}{*}{$\frac{R a a^{t} \pm}{+A z e r}$} & $\begin{array}{l}R a a^{t} \\
A w e\end{array}$ & $\begin{array}{l}86+69 \\
55+56\end{array}$ & $\begin{array}{l}\operatorname{Ra} A w e \\
a^{t}\end{array}$ & $\begin{array}{r}9+22 \\
28+30\end{array}$ & $\begin{array}{l}R a a^{t} w e \\
A\end{array}$ & $\begin{array}{l}\text { I } 3+\text { Io } \\
\text { I } 5+\text { I } 6\end{array}$ & $\begin{array}{l}R a A \\
a^{t} \text { we }\end{array}$ & $\begin{array}{l}I+I \\
O+O\end{array}$ & \\
\hline & & $141+I 25$ & & $37+52$ & & $28+26$ & & $I+I$ & $207+204$ \\
\hline & & $546+54^{I}$ & & $162+186$ & & $107+86$ & & $7+5$ & $822+818$ \\
\hline
\end{tabular}

\section{ANALYSIS}

Before estimating recombination and interference, certain standard tests for heterogeneity in the data are necessary. The tests to be used are set out fully by Parsons (I957a, I 958) and Wallace (I957a) and here it is merely proposed to give some of them very briefly with little discussion. The first is a general heterogeneity test on the $4 \times 4$ Latin square testing the agreement of observations and proportionate exicctations based upon column and row totals. As the entries in the double recombinant class are very small, they are ignored for this test. For the female data $\chi_{6}^{2}=3.07(0.7<\mathrm{P}<0.8)$ and for the male $\chi^{2}{ }_{6}=5 \cdot 10 \quad(0.5<\mathrm{P}<0.7)$, thus neither set of data reveals significant heterogeneity.

It is to be expected that the members of a pair of complementary genotypes will be unequal because of viability and possibly manifestation disturbance. However, if the data are reliable, such deviations 
from the expected I : I ratio within a complementary pair should not be heterogeneous among the four possible parental heterozygotes.

TABLE 2

Heterogeneity tests for members of complementary pairs

\begin{tabular}{|c|c|c|c|c|c|c|}
\hline \multicolumn{7}{|c|}{ 2a. Data arranged for testing } \\
\hline \multirow{2}{*}{ Genotypes } & \multirow{2}{*}{$\begin{array}{c}\text { No } \\
\text { change }\end{array}$} & \multirow{2}{*}{$\begin{array}{c}R a \\
\text { change }\end{array}$} & \multirow{2}{*}{$\begin{array}{c}\text { we } \\
\text { change }\end{array}$} & \multicolumn{2}{|c|}{$\begin{array}{l}\text { Data arranged } \\
\text { according to } \\
\text { sex of parent }\end{array}$} & \multirow{2}{*}{ Total } \\
\hline & & & & a & q & \\
\hline \multirow[t]{2}{*}{$\mathrm{A}\left\{\begin{array}{l}R a A+ \\
+a^{t} w e\end{array}\right.$} & $\begin{array}{l}134 \\
137\end{array}$ & $\begin{array}{l}39 \\
5^{2}\end{array}$ & $\begin{array}{l}33 \\
16\end{array}$ & $\begin{array}{r}\text { I I } 2 \\
94\end{array}$ & $\begin{array}{r}94 \\
\text { II I }\end{array}$ & $\begin{array}{l}206 \\
205\end{array}$ \\
\hline & 271 & $9 \mathrm{r}$ & 49 & 206 & 205 & $4^{\text {II }}$ \\
\hline \multirow[t]{2}{*}{$\mathrm{B}\left\{\begin{array}{l}R a a^{t} w e \\
+A+\end{array}\right.$} & $\begin{array}{l}152 \\
112\end{array}$ & $\begin{array}{l}45 \\
43\end{array}$ & $\begin{array}{l}23 \\
31\end{array}$ & $\begin{array}{r}113 \\
93\end{array}$ & $\begin{array}{r}107 \\
93\end{array}$ & $\begin{array}{l}220 \\
186\end{array}$ \\
\hline & 264 & 88 & 54 & 206 & 200 & 406 \\
\hline \multirow[t]{2}{*}{$\mathrm{C}\left\{\begin{array}{l}R a A \text { we } \\
+a^{t}+\end{array}\right.$} & $\begin{array}{l}\text { I } 36 \\
\text { I } 50\end{array}$ & $\begin{array}{l}31 \\
58\end{array}$ & $\begin{array}{l}19 \\
20\end{array}$ & $\begin{array}{r}99 \\
\text { I IO }\end{array}$ & $\begin{array}{r}87 \\
118\end{array}$ & $\begin{array}{l}186 \\
228\end{array}$ \\
\hline & 286 & 89 & 39 & 209 & 205 & $4^{14}$ \\
\hline \multirow[t]{2}{*}{$\mathrm{D}\left\{\begin{array}{l}R a a^{t}+ \\
+A w e\end{array}\right.$} & $\begin{array}{l}155 \\
111\end{array}$ & $\begin{array}{l}45 \\
35\end{array}$ & $\begin{array}{l}29 \\
22\end{array}$ & $\begin{array}{r}\text { II I } \\
81\end{array}$ & $\begin{array}{r}\mathrm{II} 8 \\
87\end{array}$ & $\begin{array}{l}229 \\
168\end{array}$ \\
\hline & 266 & 80 & $5^{\mathrm{I}}$ & 192 & 205 & 397 \\
\hline
\end{tabular}

2b. $\chi^{2}$ tests from data in table $2 a$

\begin{tabular}{|c|c|c|c|c|c|c|}
\hline $\begin{array}{l}\text { Geno- } \\
\text { types }\end{array}$ & $\begin{array}{l}\text { Contingency } \\
\chi_{1}^{2} \text { for sex } \\
\text { differences }\end{array}$ & $\mathrm{P}$ & $\begin{array}{c}\chi_{1}^{2} \text { for } \\
\text { overall } \\
\text { viability }\end{array}$ & $P$ & $\begin{array}{l}\chi_{2}^{2} \text { for hetero- } \\
\text { geneity between } \\
\text { members of a } \\
\text { complementary } \\
\text { pair }\end{array}$ & $P$ \\
\hline $\begin{array}{l}A \\
B \\
C \\
D\end{array}$ & $\begin{array}{l}2.65 \\
0.03 \\
0.83 \\
0.003\end{array}$ & $\begin{array}{c}0.1<\mathrm{P}<0.2 \\
0.8<\mathrm{P}<0.9 \\
0.3<\mathrm{P}<0.5 \\
\mathrm{P}>0.95\end{array}$ & $\begin{array}{l}0 \cdot 002 \\
2 \cdot 85 \\
4 \cdot 26 \\
9 \cdot 37\end{array}$ & $\begin{array}{c}\mathrm{P}>0.95 \\
0.05<\mathrm{P}<0 . \mathrm{I} \\
0: 02<\mathrm{P}<0.05 \\
\mathrm{P}<0.01\end{array}$ & $\begin{array}{l}7 \cdot 79 \\
4 \cdot 48 \\
4 \cdot 69 \\
0 \cdot 12\end{array}$ & $\begin{array}{c}0.02<\mathrm{P}<0.05 \\
0.1<\mathrm{P}<0.2 \\
0.05<\mathrm{P}<0.1 \\
\mathrm{P}>0.90\end{array}$ \\
\hline
\end{tabular}

Furthermore, there should be no difference in the magnitude of the disturbance encountered according to the sex of the triply heterozygous parent. The procedure for carrying out such tests is described fully by Parsons (1958). In table $2 a$ the data are arranged in a form suitable for a series of simple $\chi^{2}$ tests which are tabulated in table $2 b$. The double recombinant classes are ignored. 
The results of these tests show that, as expected, there are deviations from the I : I ratio expected between members of complementary pairs. Such deviations are maintained throughout the data. For the complementary pair of genotypes $R a A$ and $a^{t}$ we there is a suspicion of heterogeneity which, in view of the homogeneity of the remainder of the data, can be regarded as due to chance. No significant sex difference is detected for any of the complementary pairs.

Single-factor ratios obtained directly by addition from the observed progeny give a crude test to detect the factors responsible for the deviations from the expected I : I ratio between members of complementary pairs (table 3 ). There is a non-significant deficiency of we we mice, and a significant deficiency of $A A$ mice compared with $A a^{t}$. Hence there is only one factor of significantly poor viability and this effect is therefore equally distributed in each cell of the

TABLE 3

Single factor ratios

\begin{tabular}{|c|c|c|c|c|c|c|}
\hline & $\begin{array}{l}A . A \\
75^{2}\end{array}$ & $\begin{array}{l}A a^{t} \\
888\end{array}$ & $\begin{array}{c}R a+ \\
84^{8}\end{array}$ & $\begin{array}{l}++ \\
79^{2}\end{array}$ & $\begin{array}{l}+w e \\
856\end{array}$ & $\begin{array}{c}\text { we we } \\
784\end{array}$ \\
\hline $\begin{array}{l}x_{3}^{2} \text { for equality. } \\
\mathrm{P} .\end{array}$ & \multicolumn{2}{|c|}{$\begin{array}{c}\text { I I } \cdot 28 \\
P<0 \cdot 00 \text { I }\end{array}$} & \multicolumn{2}{|c|}{ I $9 \mathrm{I}$} & $3 \cdot 16$ & $<0 \cdot 1$ \\
\hline
\end{tabular}

$4 \times 4$ tables. In the estimation of recombination by simple addition of the column totals the effect will cancel out.

The deficiency of $A A$ mice is of interest when considered in the light of Fisher's (1949) findings that the heterozygotes $A^{Y} A^{L}, A^{Y} A$, $A^{Y} a^{t}, A^{Y} a, A^{L} A, A^{L} a^{t}, A^{L} a, A a^{t}, A a$ and $a^{t} a$ are equally viable. However, Fisher did not discuss the viabilities of the homozygotes, one of which is $A A$. Possibly, therefore, the homozygotes at the agouti locus are of somewhat lower viability than the heterozygotes.

\section{ESTIMATION OF RECOMBINATION AND INTERFERENCE}

As there is little suspicion of heterogeneity, recombination can be estimated by the simple addition of the column totals of the $4 \times 4$ Latin squares. Recombination values and Kosambi coefficients. (Owen, I950) for each sex are listed in table 4.

The recombination values show a sex difference for each segment. For $R a-A$, the male recombination value exceeds that of the female, and for the $A$-we segment the female value exceeds that of the male although neither difference is significant. The values for the entire segment are, however, very close to each other. The $A$-we values are a little greater than those given by Owen (1953) but as in his data, the female recombination value is greater than the male. The only previously published data for the $R a-A$ segment is a small amount 
presented by Carter and Phillips (I954). The values given in table 4 are a little smaller. Data in which the male recombination value exceeds that of the female in the house mouse are not common. Wallace obtained a larger value for males for the segment $f i-S d$ in linkage group $\mathrm{V}$ which was, however, not significantly different from the female. There are only three other cases where male values are greater and these are discussed by Wallace (1957a).

Interference is more severe in the male, and in both sexes the Kosambi coefficients are well below unity, indicating that the centromere is not within the segment $R a-A$-we. Hence, so far as they go, the data support the location of the centromere between $f i$ and $S d$.

TABLE 4

Recombination values and Kosambi coefficients

\begin{tabular}{|c|c|c|}
\hline $\begin{array}{l}\text { Recombination } \\
\text { in segment }\end{array}$ & Females & Males \\
\hline $\begin{array}{c}R a-A \\
A-w e \\
\text { Ra-we }\end{array}$ & $\begin{array}{l}20 \cdot 56 \pm 1 \cdot 41 \\
13 \cdot 87 \pm 1 \cdot 21 \\
32 \cdot 73 \pm 1 \cdot 64\end{array}$ & $\begin{array}{l}23 \cdot 35 \pm 1 \cdot 48 \\
11 \cdot 12 \pm 1 \cdot 10 \\
33 \cdot 25 \pm 1 \cdot 65\end{array}$ \\
\hline Kosambi coefficients & $0.45^{6} \pm 0.172$ & $0.354 \pm 0.157$ \\
\hline
\end{tabular}

Assuming Wallace's placing of the agouti locus, the terminus ( $\mathrm{T}$ ) and the centromere (C), the markers $R a$ - $A$-we give a map

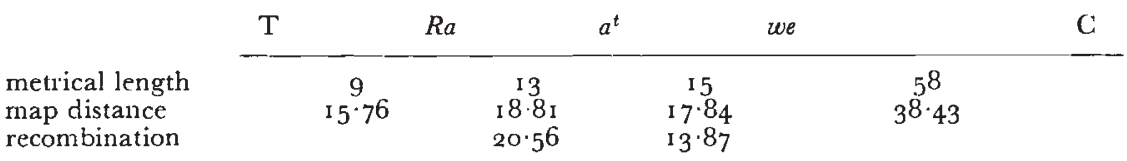

for females with a goodness of fit $\chi^{2}{ }_{3}=7 \cdot 8 \mathrm{r} \quad(0.05<\mathrm{P}<0 \cdot 1)$. This map is constructed from Fisher's segmental functions (Fisher and Yates, 1953) and it assumes Owen's (1950) $\frac{1}{4} \chi^{2}{ }_{4}$ distribution of intercept lengths. For the males, however, the fit is not so good and the following map gives $\chi^{2}{ }_{3}=9.17(0.02<\mathrm{P}<0.05)$

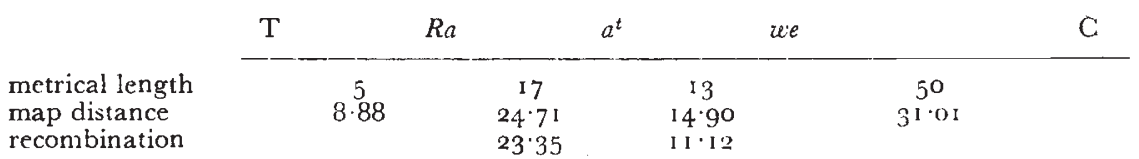

The poorer fit for the males is not unexpected as Wallace (1957b) obtained a poorer fit for $a^{t}-f i-S d$ in this sex.

In the data for which $\mathrm{K}$ values have been calculated in the house mouse (Owen, r953; Wallace, 1957a, and Parsons, 1958) it is noticeable that they have not exceeded unity, whereas on the basis of the $\frac{1}{4} \chi^{2}{ }_{4}$ metric which is supported by Drosophila (Owen, 1948) and maize (Parsons, 1957b), $\mathrm{K}$ values should exceed unity in the centromeric regions. Wallace (1957a) obtained $\mathrm{K}$ values of $0.8493 \pm$ 0.1507 in the females and $0.7113 \pm 0.2887$ in the males for the triple 
$a^{t}-f-S d$ which is a centromeric region. If this tendency for a somewhat more intense degree of interference is maintained in the future, some modification of the $\frac{1}{4} \chi^{2}{ }_{4}$ metric will be necessary for the house mouse.

\section{SUMMARY}

Three-point data are presented for linkage group $\mathrm{V}$ of the house mouse for the markers ragged, agouti and wellhaarig. It is shown that interference is reasonably intense. This is expected as the region delimited by these genes does not contain the centromere.

\section{REFERENCES}

CARTER, T. C., AND PHILLIPS, R. J. S. I954. Ragged, a semi-dominant coat texture mutant in the house mouse. 7. Hered., 45, I 5 I-I 54 .

FISHER, R. A. 1949. A preliminary linkage test with Agouti and undulated mice. Heredity, 3, 229-24I.

Fisher, R. A., AND YATES, F. 1953. Statistical Tables for Biological, Agricultural and Medical Research. $4^{\text {th }}$ edition. Oliver and Boyd, Edinburgh.

owen, A. R. G. 1948. Ph.D. Dissertation. University Library, Cambridge.

OWEN, A. R. G. I950. The theory of genetical recombination. Advances in Genetics, 3, I I 7-I 57 .

OWEN, A. R. G. I953. The analysis of multiple linkage data. Heredity, 7, 247-264. PARSONS, P. A. I957a. An effect of gene arrangement on the recombination fraction in Drosophila melanogaster. Heredity, II, I I 7 - 127.

PARsons, P. A. 1957 $b$. Genetical interference in maize. Nature, I79, I6I-162.

PARSONS, P. A. I958. A balanced four-point linkage experiment for linkage group XIII of the house mouse. Heredity I 2, 77-95.

Wallace, M. E. 1947. Two sex linkages in the house mouse with unusual recombination values. Heredity, $I, 349-354$.

WALLACE, M. E. I957a. A balanced three-point experiment for linkage group V of the house mouse. Heredity, $I I, 223-258$.

WALLACE, M. E. I957 b. The use of affinity in chromosone mapping. Biometrics, I3, 98-I IO. 